\title{
The Historical Role of Women in Higher Education
}

\author{
Patsy Parker, Ph.D. \\ Southwestern Oklahoma State University
}

\begin{abstract}
Historically, females, as compared to males, have represented a lower percentage of college professors and administrators in the United States. The tendency for males to outnumber females in the professoriate and college administration has existed since United States higher education institutions formed in the early 1800 s and still persists today. Fluctuations in women's participation rate have been influenced by the economy's history and society's expectations of females. Observation of the employment trends for females offers an interesting look at the evolving role of women in the United States workforce, in general, and in the university setting, in particular.
\end{abstract}

Keywords: leadership, higher education, gender, female leadership

T

he role of female professors and administrators in United States higher education has evolved, with some interesting twists and turns, since the early 1800s. Even when female employees were rare in business settings, women found their niche in teaching. However, certain events in United States history called for women to play important roles in business as well as education. Observation of the employment trends for females offers an interesting look at the evolving role of women in the United States workforce, in general, and in the university setting, in particular.

In Black Women and White Women in the Professions, Sokoloff (1992) defined "the professions" as the elite occupations, such as law, medicine, architecture, ministry, dentistry, judicial positions, science, and university teaching. These areas qualify as being distinct because the professions are awarded a high degree of honor and status in United States society, and the employees in these areas have traditionally received substantial internal and monetary rewards for the services they provide. The autonomy of the professionals and the esteem that accompanies their positions can be attributed to the high levels of education they have achieved. The specialized training they have pursued allocates to them a large body of knowledge and allows them to be classified as experts in their chosen fields. Sokoloff's study revealed that, during the two decades from 1960 to 1980, these professional areas constituted the highest-paid occupations and provided the greatest amount of autonomy and control to white males, the group that comprised the majority of the employees in the professions. 
The semiprofessions were occupations that were not as elite as the professions, but did require some level of education. They included occupations such as elementary teaching, nursing, librarianship, and social work $-a$ list that reflects a female-saturated group of positions. During the decades between 1960 and 1980, white males were predominant in the world of the professions; white females were predominant in the world of the semiprofessions. However, during this same time period, Sokoloff noted, tremendous changes occurred for women in the workforce.

In order to discuss the role of women in higher education, particularly in the professoriate and administration, it is necessary to observe the role of women in the work force and how the percentages of females in various occupations, but particularly in the professions, have fluctuated during the history of the United States. The following discussion focuses on the occupational groups called the professions.

\section{BACKGROUND}

Between 1870 and 1930, the percentage of women represented in the occupational groups called the professions increased from $5 \%$ of all employed women in 1870 to $14 \%$ in 1930 . The next 20 years saw a decline in the percentage of women in the professions due to the Great Depression. In 1950, only 10.8\% of professionals were female. Until 1960, professionals were predominately white males; women and minority men were mostly excluded from the elite group of occupations. For example, in 1960, women represented one-third of the labor force, but made up only $3.5 \%$ of all lawyers, $5.8 \%$ of clergy, $6.8 \%$ of doctors, and $4.2 \%$ of physicists (Oppenheimer, 1970). At United States universities, women taught in the "soft" areas of curriculum, such as foreign languages, literature, and home economics (Kaufman, 1984). During the 1960s, the percentage of professional women increased slowly, but not until 1970 would women again claim $14 \%$ of the positions in the professions, the same percentage they had claimed in 1930 (Bernard, 1971).

During the first half of the twentieth century, women were not prevented from training for or practicing the professions in the same way as men. Barriers for women included legal restrictions, quotas, administrative regulations, and anti-nepotism rules (Cott, 1987). Quotas restricted women's access to higher education as universities set limits to the number of females they would admit. For example, under Stanford's quota system, three males were accepted for every female. In 1969, Yale also set quotas for admittance of women (Minnich, n.d.). Legislation in the 1960s and 1970s that demanded equal treatment of men and women helped eliminate some of these barriers.

Aside from barriers, there are other reasons why women have continued to have such low representation in some of the top professions, many of them imposed by women themselves. One reason is that many women have simply preferred the female-dominated semiprofessions to the maledominated professions. National census data reported by The American Association of University Women (2003) indicated the highest proportions of women's college degrees were obtained in the traditionally female careers of teaching and nursing. Many women are still drawn to careers in nursing, elementary teaching, and social work. Part of the joy of the American dream is for each person to find the occupation that suits them best, striving to find their place in the career of their choice. Whether that career choice includes a high-paying job that requires several years of postgraduate education or a less-well-paying job requiring only a six-week training period, it is each person's right to choose the path 
most appealing to him or her. With so many women pursuing training in the semiprofessions, one must assume that careers in the semiprofessions have a significant measure of appeal.

Another reason for lower representation of women in the professions is that, although the percentages of women in male-dominated fields have increased in recent years, many women, even in today's society, are not as career-oriented as men. Other duties and tasks take precedence over a career, and women may spend time raising children or supporting a husband who is pursuing education or his way up the professional career ladder. Women's responsibilities in childbearing and domestic duties can infringe on or delay the pursuit of a career. Some women, either because of personal preference or the responsibilities of motherhood, will choose a lower-paying job that requires less education. On the other hand, many women with mothers and grandmothers who were domestic housewives and mothers have chosen not to follow in the footsteps of their previous generations and found joy in the fulfillment of a successful career. Each person and each generation chooses various paths.

Although women have represented a low percentage of the workforce holding a professional position, the percentage of females in the professions is increasing. The United States Bureau of Labor Statistics (2014) indicates females now hold $47 \%$ of "professional and business service" positions. In addition to discussing the reasons for women's low percentage of representation in the professions, it is imperative also to observe the reasons that percentage of representation is increasing. The rise in cost of living is one reason there is an increase in women entering demanding, satisfying careers, such as college teaching and college administration. Few families can survive on one salary and maintain a comfortable standard of living. The rise in the cost of many items greatly exceeds inflation. Today's families demand an improved lifestyle, but that lifestyle comes with a cost. Table 1 features information gathered from the United States Census Bureau (2014) and the Center for Disease Control (2014) and indicates how the standard of living changed between 1970 and 2013.

Table 1

Changes in Lifestyle in the United States

\begin{tabular}{lcccc}
\hline \multicolumn{1}{c}{ Item } & 1970 & 1990 & 2005 & $2012-2013$ \\
\hline Average size of new home in square feet & 1500 & 2080 & 2412 & 2598 \\
Homes with two or more cars & $29 \%$ & $54 \%$ & $56 \%$ & $61 \%$ \\
Median household net worth & $\$ 24,217$ & $\$ 48,887$ & $\$ 58,902$ & $\$ 68,828$ \\
Average work week & 37.1 hours & 34.5 hours & 34.5 hours & 47 hours \\
Life expectancy & 70.8 years & 75.4 years & 77.8 years & 78.7 years \\
\hline
\end{tabular}

Note. Recent data was available and reported over a two year period. United States Census Bureau. (2014). Retrieved from http://www.census.gov. Center for Disease Control and Prevention. (2014). National Center for Health Statistics. Retrieved from http://www.cdc.gove/nchs.

In previous eras, men were typically the breadwinners in the family, but it is now up to women to join the workforce to maintain or improve the North American family's standard of living. Each woman has 
choices when faced with this decision. Should she take a low-paying job with few benefits or invest in a college education and enjoy a higher-paying job with good benefits that also brings her a sense of accomplishment and satisfaction? For most women, the chance to enjoy a self-esteem boost and the increased earning power that accompanies a college education is a sensible choice.

The typical American family has also changed. Today, one in two marriages ends in divorce, and many couples choose to forgo the formality of marriage. In 1970, only $33 \%$ of marriages failed (United States Census Bureau, 2014), and marriage was more common than cohabitation. Whether it is due to divorce or to a single woman choosing to become a mother, there are many more single-parent homes in the United States now than in the past. This change has precipitated a need for women to join the ranks of executives and strive to climb the ladder in the corporate world that was once occupied primarily by white males.

\section{WOMEN IN HIGHER EDUCATION}

Having discussed the scope of women's employment in the United States and the changing roles of women during previous generations, narrowing the scope to women's roles and employment in higher education institutions elicits some interesting points.

In the 1830s and 1840s, women's desire to attend higher educational institutions created a great debate that lasted a century (Gordon, 1997). Conservatives claimed it would destroy the role of women in the household as homemakers, wives, and mothers. Liberals, on the other hand, claimed that a collegeeducated woman would be a better homemaker, wife, and mother. At a time when most Americans received only a primary or secondary education in a coed environment, a college education was seen as something that warranted separation between males and females.

During the antebellum era prior to the Civil War that began in 1861, two private colleges, Oberlin and Antioch, allowed coeducation. Oberlin College in Ohio was the first to admit women and men of all races in 1837 (Minnich, n.d.). Some classrooms were mixed audiences of males and females, but many were exclusively male. Extracurricular activities were segregated, and male/female relationships were closely monitored. Female students and faculty at both colleges resisted the segregation, wanting women to have freer access to classes and activities (Gordon, 1997). The clearly defined roles required that men studied Greek and Latin and prepared for the ministry, while the women cooked, washed, and cleaned. In fact, 1837 policy at Oberlin dismissed female students from Monday classes so they could do the male students' laundry (Tuttle, 2004).

Women's colleges were founded in the 1800s in response to a need for advanced education for women who were not allowed into most higher education institutions. The three main types of women's colleges evolved after their origin in the early 1800 s were independent private colleges, catholic colleges, and public colleges. During this time period, the independent, nonprofit women's colleges' main objective was providing liberal arts education to women. Most of the early women's colleges were located in Northeast United States, but the South also had some women's colleges that were affiliated with Protestant churches. 
During a 24-year span that began in 1836, seven significant women's colleges were founded. The "Seven Sisters" were independent private colleges that paralleled the men's Ivy League schools of the time period. They were Barnard, Smith, Mount Holyoke, Vassar, Bryn Mawr, Wellesley, and Radcliffe. A total of 50 women's colleges were founded between 1836 and 1875, but these seven had distinction. The Seven Sisters had financial resources the others lacked, and they also offered high quality academic programs. Another trait that made these seven institutions distinct is that they were able to recruit and maintain a high percentage of female faculty members (Harwarth, Maline, and DeBra, n.d.). Due to the segregation of men and women and the predominance of males at higher education institutions, female professors were excluded from faculty positions at men's colleges. However, women were the leaders of the Seven Sisters and other women's colleges during this historic time.

As alumni, the first generation of female college students demonstrated their dedication to academics by serving at women's colleges as professors, deans, and administrators at coed institutions. Female students at the colleges first founded in the eastern United States soon realized how advantageous it was to have women faculty and administrators who went to great efforts to improve curriculum and extracurricular activities for female students (Gordon, 1997).

Dean of Women was the first administrative position offered to females in coeducational institutions. Women were employed as Deans of Women as early as the 1890s (Schwartz, 1997). These positions became necessary because of the sharp increase in the female population on college campuses. In 1870, women accounted for only $21 \%$ of the undergraduate population. By 1890 , the percentage had climbed to 47 . Because of this large increase in women on college campuses, college presidents began to hire females to serve as faculty, advisors, and counselors for the female students. "Dean of Women" was the new title assigned to these women leaders.

The responsibilities of these deans from the years 1890 to 1930 were multifaceted. They were to oversee the relatively new minority population of women, which involved insulating the men from the women and, at the same time, protecting and guiding the women. Most of the deans were faculty, so their primary responsibility was teaching. These deans had the scholarly development of the women at the forefront of their concern (Schwartz, 1997). Many presidents and college leaders continued to be uncomfortable with women on campuses, so the deans of women were the solution to providing segregation and assuring that the women would remain separate from the males.

The first Dean of Women was Alice Palmer, who was appointed the position at the University of Chicago in 1892. Along with the dean's job, she also accepted the responsibility of a professor of history. Subsequently, Palmer was president of Wellesley College until she resigned after she married. At the time of her appointment at the University of Chicago, she and her husband resided in Boston. Her husband was offered a position along with her, but he declined. Palmer served in the position for three years before resigning. She was succeeded by her good friend Marion Talbot (Schwartz, 1997).

Very early, the deans began forming profession organizations. One such organization was the National Association of Deans of Women (NADW). In 1903, Talbot called the first meeting of the NADW, and it brought together 17 Deans of Women who covered an agenda that included women's housing, etiquette training, women's self-government, leadership opportunities for women, and women's 
intercollegiate athletics. At this meeting, the deans passed a resolution condemning "gender segregation in higher education" (NADW, 1927).

Many of the Deans of Women at that time were enthusiastic about pursuing graduate degrees. In response to this demand, in 1916, Teacher's College of Columbia University established a graduate program to train Deans of Women. Teacher's College produced some very accomplished researchers and skilled administrators.

During World War II, higher education institutions in the United States, along with business organizations, had declining numbers of male enrollment and male faculty. This provided an opportunity for women as students and professors in higher education in both coed and women's colleges (Harwarth, Maline, and DeBra, n.d.). With a large portion of the male population at war, women filled the roles and positions left vacated by the men. Many women took advantage of these opportunities to be college leaders and proved their capabilities in the process.

From the late 1800s through 1945, which is the year World War II ended, the Deans of Women established foundations of practice for students and administration, developed professional associations, conducted research, improved college environments, and developed a body of literature in journals, reports, and books. The early female deans had many duties in addition to providing students with guidance and counseling. In The Dean of Women, Lois Mathews (1915) provided an apt metaphor for describing the variety of responsibilities the deans of women faced. She stated that a dean must "win her spurs in the classroom."

In 1928, a study was conducted by Jane Jones (as cited by Schwartz, 1997), a graduate student at the Teacher's College. The study included 263 Deans of Women and provided the following statistics: 91\% had a bachelor's degree, $57 \%$ had a master's, and $15 \%$ had earned a doctorate. Of the 263 deans, $75 \%$ also held academic rank. The breakdown of their rankings was as follows: $9 \%$ were instructors, $13 \%$ were assistant professors, $13 \%$ were associate professors, and 40\% were professors. This group of females reported teaching in 36 academic areas. Clearly, these women earned their paychecks, dedicating time and tremendous effort to the profession and to female students.

In the 1930s, 1940s, and 1950s, psychology and vocational education became popular demands on college campuses. The Deans of Women generously took the necessary steps to develop these curriculums across the country. By the 1940s, the Deans of Women had firmly established themselves in higher education administration and provided a path for other women to follow (Gordon, 1997).

After World War II, the position of Dean of Women and other women involved in higher education was threatened because of declining female population on college campuses. Although never fully accepted on college campuses, women's numbers had climbed consistently through the 1920s. The combination of the Great Depression in the 1930s and the start of World War II-in 1939 caused attention to sway away from education. After World War II ended in 1945, the United States' attention was still not on education, but was instead focused on the role males had played in the war defending the country. Although men's admirable efforts and sacrifices should not be minimized, the women who had filled the 
roles as professors and deans at college campuses in the absence of men were now overshadowed when the male war heroes came home.

In the late 1940s, the title of the position of "Dean of Women" was increasingly becoming the "Dean of Students," with the office being filled by a male with a woman as his subordinate who served as a liaison for women students. The threat to the role of Dean of Women came not only in the elimination of the position in some cases, but also in the loss of authority. Prior to this transition, the position was most often filled by a woman who reported directly to the president of the university. This provided an opportunity to sit on policy-making committees and to be a strong voice for female students and faculty. Losing the direct line to the president caused the position to be much less influential. In a 2004 National Association of Student Personnel Administrators (NASPA) symposium report, the decreasing number in the percentage of Deans of Women indicated the loss of power. In 1940, 86\% of the deans reported to the president. In 1962, the percentage had fallen to $30 \%$. In 1971 , only $10 \%$ reported to the president, and in 1976, a mere $4 \%$ reported to the president (Tuttle, 2004).

The female population on college campuses decreased to a mere $21 \%$ by the mid-1950s, causing a general erosion of the respect and prominence of women on college campuses. The attitude on campuses became apathetic, even hostile in some cases, toward women. Although women had no problem gaining access to colleges as students, this attitude caused numbers of women on campuses and in the work force to decrease steadily. Records indicate that women terminated from their jobs made up $60 \%$ of all workers released in the months immediately following World War II. Women were terminated at a rate $75 \%$ higher than men (Schwartz, 1997). Subsequently, women had no choice but to opt for domestic roles at home. All of these occurrences contributed to the birth of the baby boom generation in the 1940s and 1950s.

The move in the 1960s and 1970s toward equality in the work place and in education encouraged the changing of the roles of women in higher education administration and faculty. The 1964 Civil Rights Act called for equal treatment of minority groups and the elimination of sexual discrimination. Title IX of the Education Amendments of 1972 provided protection for employees and students in educational institutions. The governmental legislation and the strong movement to gain equality lead higher education institutions to become organizations based on function and not gender (Tuttle, 2004). If the legislation were to be followed, colleges had no choice but to decrease the attention they had previously given to women's campus needs and attempt to treat men and women as equals.

From 1950 to the present, males have assumed the roles of the majority of presidents, vice-presidents, deans, and other top administrative positions on college campuses. There are substantial numbers of women in education and administration graduate programs, but a predominantly male population is filling the offices that manage higher education. Since 1979, women have earned more than half of all bachelor's degrees and master's degrees and one-third of all doctorates. Despite this high representation of women as students, by 2012 , about $86 \%$ of all presidents, provosts, and chancellors were male, and $75 \%$ of full professors were males (American Association of University Professors, 2012; Stripling, 2012). Additionally, data indicates female professors, when compared to males, move up the career ladder slower, are less productive, have heavier teaching loads, and have lower salaries. 


\section{CONCLUSION}

Although women have not had the opportunity to represent a strong proportion of higher education professors or administrators, it is important to look at the whole picture prior to being too critical about women not having an equal share in higher education leadership. The fact that men and women have separate and unique roles is a very plain, simple, unavoidable truth. Every person has unique talents, and men, in general, have been socialized to be authoritative and dominant while women, in general, have been socialized to be the more nurturing and less dominant. This issue was discussed by Hills and Rowan (2002), and the two researchers raised some important questions. They asked, "Is it better for women to assert their sameness to, or their difference from, men in their quest for 'equal' rights?" To claim sameness is to have women defined by the male norm. In some cases, this would be fine, but in others, it would be unfair. To claim that women are different says that women need different kinds of support, different opportunities, and different standards. It would also indicate that women would be likely to respond in different ways and for different reasons (Hills and Rowan, 2002).

Wars, military conflicts, and terrorist attacks have a way of dividing our past into time segments. We note the changes in the economy before, during, and after the historical events because of the farreaching effects these conflicts have on our country and the rest of the world. In researching higher education, many of the changes in higher education occurred because of war. In observing the sometimes inconspicuous role of women in higher education, we must consider the fact that women were playing a vital role in the progression of the higher education institutions during the times when much of the male population was fighting wars. The fact that women were pushed aside after the men came home was a circumstance of society that was unavoidable. Both genders excelled at what they did best. They cultivated their talents and used those talents to benefit themselves, their families, and their country. If a man wished to take an active part in one of our country's early wars, he helped fight battles; if a woman wished to take an active part in one of the early wars, she helped nurse the injured. Some of the women who stayed behind, not taking an active part in the battlefields or hospitals, followed their aspirations and created their place on college campuses across the United States. Both men and women played important parts in the evolution of our country and its higher education system. Our higher education system would not have progressed as well during wartime had it not been for women taking these leadership roles.

As researchers investigate the reasons behind the gender gap, we are reminded that there is an increasing awareness of the problem. Mentoring has long been suggested as a way to increase female representation in leadership roles. However, Hackney and Bock (2000) believe mentoring is no longer as effective as it once was. In a world in which people respond to horizontal guidance better than vertical leadership and the traditional hierarchy, mentoring is seen as a dominating form of guidance. In academics, a caring faculty member, one that works side by side with aspiring leaders, is more effective than a formal mentor. The implications provided by Hackney and Bock are that such a partnership, instead of a mentorship, would help eradicate inequality in women's roles on campus.

When we observe how much more gender-blended we are today than several decades ago, it is obvious that women have made progress and are gaining the recognition and the opportunities to fill positions previously held solely by men. This is occurring not only in higher education, but in other arenas as well. 
A good example of how opportunities are being made accessible to women is the number of women the Department of Defense (2006) now has on the active duty military roster. The ratio of females to males serving in active duty has increased substantially from 1945, when only $2.2 \%$ of the active duty personnel were female, to $15 \%$ in 2003. Table 2 indicates that women are taking a more active part in military actionsk, as evidenced by the increasing percentage of women on active duty in the Army, Navy, Marine Corps, and Air Force from 1945 to 2006 (Department of Defense, 2012).

Table 2

Females in Active Duty, 1945 to 2013

\begin{tabular}{c|c}
\hline Year & Percent of Females Included in Active Duty Personnel \\
\hline 1945 & $2.2 \%$ \\
1960 & $1.2 \%$ \\
1970 & $1.3 \%$ \\
1980 & $8.3 \%$ \\
1990 & $11.1 \%$ \\
2000 & $14.6 \%$ \\
2010 & $15 \%$ \\
2013 & $15 \%$ \\
\hline
\end{tabular}

Note. Recent data was available and reported over a two year period. Department of Defense. (2014) Retrieved from http://www.defense.gov.

Data is occasionally gathered concerning women's representation in higher education administration and faculty. In one such study, a group of researchers gathered information on community colleges and their female leaders. Community colleges typically have a larger percentage of female representation than comprehensive and four-year institutions. The data indicated that in $1985,16 \%$ of community colleges' leaders were female. In 1990, the percentage had increased to $21 \%$; in 1994 , to $27 \%$; and in 2000 , to $39 \%$. These researchers also stated that women comprised $39 \%$ of community colleges faculty (as cited by McKenney and Cejda, 2001). A 2001 U.S. Department of Education report supported these figures by stating that in 1992, 39\% of full-time instructional faculty was female (as cited by Christman, 2003). This is a fairly impressive representation of female leaders at the community college level. However, at comprehensive institutions and four-year universities, the female representation is much lower.

Currently, 26\% of the nation's colleges and universities are led by women (American Council on Education, 2013). The percentage has increased significantly since 1986, when The American Council on Education (n.d.) reported that slightly over $9 \%$ of United States college presidents were women. In 2002, 19\% of United States' college presidents were women (American Council on Education, 2002). 
In a 1983 report concerning the status of women in the academic profession, the American Association of University Professors admitted that there were few women faculty in most academic fields and the women that were currently in higher education academics tended to be in part-time and temporary positions. The report went on to question whether discrimination had truly been eliminated and suggested that effective affirmative-action plans should be implemented (American Association of University Professors, 1983). Although this statement was written over three decades ago and concerned women faculty, the problem of low representation of females in higher education persists today.

United States' higher education institutions have very capable, successful women that serve as presidents and provosts of today's public and private coed institutions. They enjoy leading some of the most prominent institutions in the country. The women who dedicated their lives to higher education in the 1800 s and early 1900 s played a vital part in paving the way for today's female college leaders. There is no doubt that the past Deans of Women and female professors had the ability to be effective presidents of any college, but they were given the opportunity only at women's colleges. Today's representation of females in administrative positions and the professoriate is much higher than in the past, even as recently as the 1960s and 1970s. Women today are given the opportunity for advancement as never before in higher education. Sally Helgesen (1990) described the progressive movement in her book The Female Advantage, by saying that organizations are "moving beyond gender, in response to organizational need" (Helgesen, p. xviii). Over twenty years ago, Helgesen optimistically predicted that women would be welcomed into positions of authority until a comfortable balance of males and females existed in organizations. In looking at the increase in women in higher education faculty and administration since Helgesen wrote these words, her prediction certainly seems to have merit. Perhaps the next decades will bring more fast-paced aggressive increases in the number of women serving in higher education top administrative positions.

\section{REFERENCES}

American Association of University Women (2003, Spring). Women at Work. Retrieved from http://www.aawu.org/research/womenatwork.cfm.

American Association of University Professors. (1983). Affirmative action plans: Recommended procedures for increasing the number of minority persons and women on college and university faculties. Retrieved from http://www.aaup.org/statements/Redbook/AARDPLAN.HTM.

American Association of University Professors. (2012). Distribution of Faculty, by Rank, Gender, Category, and Affiliation, 2011-2012. Retrieved from http://ww.aaup.org,

American Council on Education. (2002). Characteristics of College Presidents. Retrieved from http://www.acenet.edu

American Council on Education. (2013). The CAO Census. Retrieved from http://www. acenet.edu.

Bernard, J. (1971). Women and the Public Interest: An Essay on Policy and Protest. Chicago: AldineAtherton. 
Center for Disease Control and Prevention. (2014). National Center for Health Statistics. Retrieved from http://www.cdc.gove/nchs

Christman, D. (2003, Winter). Women faculty in higher education: Impeded by Academe. Advancing Women in Leadership. Retrieved from http://www.advancingwomen.com/awl/winter2003 /christ\%7E1.html.

Cott, N. (1987). The grounding of modern feminism. New Haven and London: Yale UP.

Department of Defense. (2014). Retrieved from http://www.defense.gov.

Gordon, L. (1997). From seminary to university: An overview of women's higher education, 1870-1920. In L. Goodchild \& H. Wechsler (Eds.), The history of higher education ( $2^{\text {nd }}$ ed.), (pp 473-498). Needham Heights, MA: Simon \& Schuster Custom Publishing.

Hackney, C., \& Bock, M. (2000, Spring). Beyond mentoring: Toward an invitational academe. Advancing Women in Leadership. Retrieved from http://www.advanacingwomen.com/awl/winter2000 /hackney-bock.html.

Harwarth, I., Maline, M., \& DeBra, E. (n.d.). Women's Colleges in the United States: History, issues, and challenges. Retrieved from http://www.ed.gov/offices/OERI/PLLI/webreprt.htm/.

Helgesen, S. (1990). The female advantage. New York: Bantam, Doubleday, Dell Publishing Group, Inc.

Hills, E., \& Rowan, L. (2002, Winter). Feminist academics as nomadic subjects: Reconceptualizing women in universities. Advancing Women in Leadership. Retrieved from http://advancingwomen.com/awl/winter2002/hills_rowan.html.

Kaufman, D. (1984). Women: A feminist perspective, (3 ${ }^{\text {rd }}$ ed.) Palo Alto, CA: Mayfield.

Mathews, L. (1915). The dean of women. Cambridge, MA: Riverside Press.

McKenney, C., \& Cejda, B. (2001, Summer). The career path and profile of women chief academic officers in public community colleges. Advancing Women in Leadership. Retrieved from http://www.advancinwomen.com/awl/summer2001/cejda_mckenney.html.

Minnich, E. (n.d.). Reader's Companion to U.S. Women's History. Houghton Mifflin College Division. Retrieved from http://college.hmco.com/history/readerscomp/women/html/wh_011000 _education.htm

NADW. (1927). National Association of Deans of Women. Yearbook of the National Association of the Deans of Women. Bloomington: Library, Indiana University.

Oppenheimer, V. (1970). The female labor force in the U. S. Berkeley: U of California P.

Schwartz, R. (1997). How deans of women became men. The Review of Higher Education, 20(4), 419436.

Sokoloff, N. (1992). Black women and white women in the professions. New York: Routledge, Chapman and Hall, Inc.

Stripling, J. (2012, March 12). Survey finds a drop in minority presidents leading colleges. Chronicle of Higher Education. 
Tuttle, K. (2004). The historical perspective of women administrators in higher education. 2004 NASPA Alice Manicur Symposium. Lawrence, Kansas: University of Kansas.

United States Bureau of Labor Statistics (2014). Issues in Labor Statistics. Retrieved from http://www.bls.gov .

United States Census Bureau. (2014). Retrieved from http://www.census.gov

\section{ABOUT THE AUTHOR}

Patsy Parker, Ph.D. (patsy.parker@swosu.edu) is a department chair and tenured associate professor in the Everett Dobson School of Business and Technology at Southwestern Oklahoma State University (SWOSU). Dr. Parker earned a doctor of philosophy degree from the University of Oklahoma. Her dissertation focused on female leadership, and she has subsequently published and presented at national conferences. Dr. Parker has served as a member of SWOSU's Higher Learning Commission Steering Committee, co-chairing the criterion that targeted student learning and effective teaching. In addition to teaching, she currently serves as managing editor for the Administrative Issues Journal, a Tier 1 professional journal. Dr. Parker is active in community service through Rotary International, the local Chamber of Commerce, and American Association of University Women. Phone: 580-774-3284 